\title{
ENHANCED EDDY CURRENT TECHNIQUES FOR DETECTION OF SURFACE-BREAKING CRACKS IN AIRCRAFT STRUCTURES
}

\author{
Valentyn Uchanin (iD 0000-0001-9664-2101 \\ Karpenko Physico-Mechanical Institute of National Academy of Sciences of Ukraine \\ Naukova str. 5, Lviv, Ukraine, 79060 \\ vuchanin@gmail.com
}

\begin{abstract}
Well-timed detection of the defects (e.g., fatigue cracks and corrosive damages) in aircraft structures is the question of vital importance. Periodic in-service non-destructive inspection (NDI) is necessary to prevent expensive aircraft breakdowns during in-service life. Eddy current (EC) NDI method have many advantages for in-service aircraft inspection due to high mobility and the possibility to detect fatigue cracks without direct contact with the inspected surface (even through a protective coating without removal). Last decades some enhanced EC techniques were developed for aircraft in-service inspection in the Karpenko Physico-Mechanical Institute of National Academy of Sciences (Lviv) in collaboration with Ukrainian and foreign aircraft companies.

Proposed earlier EC efficiency coefficient was applied for the selection of the ferrite-core EC probe parameters. Investigations concerned with the crack detectability for single-coil EC probes of different sizes were carried out to improve the inspection procedures. The sensitivity of the developed single-coil EC probe was experimentally investigated. The possibility to distinguish the signals associated with detected defect and lift-off was shown. The new inspection procedure was proposed for full suppression of the noise concerned with the rivet edge influence.

The high-frequency EC flaw detector of Leotest VD 3.03 type based on self-generator mode and miniature single-coil EC probes application was developed for detection of the surface-breaking fatigue cracks. The original scheme of double-circuit self-generator with intermittent oscillations was invented and investigated. The pulse-repetition frequency of high-frequency oscillations was used as an informative parameter. The important feature of the developed self-generating scheme is the effective suppression of the lift-off influence (the changes of the clearance between the EC probe and the inspected object surface during the scanning).

Developed EC flaw detectors of Leotest VD 3.03 type and inspection procedures were successfully implemented into the maintenance practice for detection of the fatigue cracks initiated in the wing and the fuselage structures and aviation engines in many companies such as ANTONOV AIRCRAFT, Lviv State Aircraft Repair Plant, Konotop aircraft repair plant "AVIAKON», Ukrainian International Airlines, MOTOR-SICH, State Enterprise "IVCHENKO-PROGRESS", etc.
\end{abstract}

Keywords: eddy current (EC), EC flaw detector, single-coil EC probe, complex plane, aircraft structure, fatigue crack, self-generating scheme, lift-off.

Type of the work: Technical Paper 


\section{INTRODUCTION}

Regular maintenance of aircraft structures and engine components plays a vital role for in in-flight safety assurance. Incidentally, nondestructive inspection (NDI) is one of the most important parts of maintenance strategy [1-3]. NDI methods are needed to assure the aircraft airworthiness and used throughout a life cycle - from new aircraft design and production to periodical in-service inspections of the most critical components. Periodic in-service NDI is necessary to prevent expensive breakdowns during the operation.

Various NDI methods applied for aircraft maintenance have appropriated advantages and disadvantages concerned with simplicity of inspection procedures, sensitivity to the defects of different types, testing reliability and productivity, the low cost of inspection tools and expendable materials, etc.

The eddy current (EC) NDI method has long been widely applied to inspect structure and component fabricated from conductive materials to identify their structural integrity [4-9]. Since the 1950s the role of EC inspection has developed increasingly, especially in the aerospace and nuclear industries. The principle of the EC technique is based on the interaction between an electromagnetic field produced by the EC probe with the inspected material [4]. Designated interaction induces eddy currents in the inspected component and even very small cracks can be detected and monitored due to changes in eddy current flaw related to a crack. The EC method has several advantages as compared to other methods applied in aircraft due to high inspection sensitivity, productivity, reliability, the possibility to detect defects without direct contact with an inspected surface (even through the different coatings without removing) [5-7]. EC techniques are generally used to detect fatigue cracks and corrosion damages near the surface of metallic aircraft structures and components like fuselage, wings, wheel discs, engine blades and turbine, rotors, axles, brackets, landing gears, etc. [6, 7]. EC method is also applied for non-magnetic alloys heat-treatment verification and aluminum alloys degradation monitoring by the noncontact electrical conductivity measurements [7, 8].

Last five decades, the high-frequency EC method is one of the most sensitive NDI methods generally used to detect shallow cracks (e.g. originated by fatigue) in metallic components of aircraft structures even through the dielectric coating. Hand-scanned EC probes can detect small cracks in difficult for access areas like rivet holes. At the same time, EC inspection techniques are specifically sensitive to a variety of factors (apart from defects) that affect the response of the EC probe and conventional EC instruments observe the related variations of the EC probe impedance. These factors include the electrical conductivity and magnetic permeability of the inspected material, geometric parameters, and the clearance between the probe and the inspected surface (lift-off). Experienced ET operators aim to eliminate or reduce these disturbances to achieve consistent and reliable results. Lift-off and inclination of the EC probe are especially dangerous for manual EC inspection. The lift-off variations produced by inspected surface roughness or dielectric coating thickness also can result in false calls. Therefore, a high level of lift-off effect suppression is needed to obtain reliable indications. This generally requires trained and experienced operators to interpret the inspection results. Recent trends in EC technique development are directed to the improving capabilities to detect short and shallow defects with high reliability based on the high level of disturbing factors suppression. The inspection reliability can be estimated by the probability of detection (POD) as a statistically based quantitative measure. Even for the same EC equipment, the POD is affected by several factors such as material properties, structural details, defect shape, inspection conditions, etc. Another parameter associated with POD is the confidence level with which a defect can be detected. A 95\% confidence level is considered acceptable for flaw detection. An NDI equipment capability is generally designated as a $90 \%$ probability of detecting a defect with a $95 \%$ confidence level [9]. The applicable selection of the EC inspection technique as well as the correct adjustment of the inspection parameters can increase the POD and assure the integrity of the aircraft components over its in-service life. 
There is statistical data on the size distribution of fatigue cracks that have been identified in aircraft structures [9]. It was shown that fatigue cracks have a predominantly semi-elliptical shape with a different shape factor $a / l_{C r}$ determined as the ratio of crack depth $a$ to crack length $l_{C r}$. It was revealed that the shape factor for fatigue cracks was distributed between $a / l_{C r}=0.5$ and $a / l_{C r}=0.05$. Corrosion pitting have shape factor $a / l_{C r} \geq 1.0$. By tension fatigue cracks having $a / l_{C r}=0.5$ are generated. The bending stresses tend to propagate the crack length at a faster rate. In this study, it was mentioned also that for fatigue crack is typical when the depth is one-half the length. Generally, it is difficult to detect short (even deep) defects like corrosion pitting and shallow (even long) cracks.

In this paper, some principal aspects related to the detection of surface-breaking defects in aircraft structures are investigated. The peculiarities of proposed EC techniques for reliable detection of defects in metallic aircraft structures are presented.

\section{INVESTIGATIONS CONCERNED WITH EDDY CURRENT PROBE FOR SURFACE-BREAKING CRACK DETECTION}

\subsection{General considerations related to EC probe selection}

Several requirements to an EC inspection technique for surface-breaking cracks have been considered as important for aircraft application, such as the selection of EC probe type to obtain high detectability; the selection of EC probe geometrical parameter for reliable detection of the cracks which dimensions characterize the sensitivity threshold; simple signal interpretation possible to separate useful indications created by cracks from indications related to disturbing factors like lift-off or edge influence; the convenience to operate in the field or airport conditions (small size, low power consumption, and accumulator battery, etc.) [10].

Practically, for routine aircraft applications, the sensitivity threshold of EC instrumentation was established as the possibility to detect $2 \mathrm{~mm}$ long and 0.2 deep like crack defects. This defect must be detected even through the dielectric coating as thick as $0.5 \mathrm{~mm}$. In this case, the covered aircraft components will be inspected without an expensive procedure of the coating removal.

Different types of EC probes possible to be applied for the detection of surface-breaking cracks in aircraft structures are reviewed and analyzed in our papers $[11,12]$. At the same time, the simplest singlecoil EC probe with one-layer winding mounted on ferrite core was selected as the most advantageous for the detection of the short cracks in hand scanning mode (fig. 1a). Inestimable advantages of single-coil EC probes are concerned with the independence of the probe sensitivity on the crack direction, the design simplicity, the performance repeatability, small size, and low price. Due to these peculiarities, single-coil ferrite core EC probes are widely used for aircraft inspection [7, 10, 13-16]. EC probes with one-coil mounted on ferrite core are used in EC flaw detector based on the resonant mode application like DEFECTOMETR family flaw detectors such as DEFECTOMETR 2.837 developed by Institute Dr. Foerster GmbH \& Co. (Reutlingen, Germany) and VD-10A type flaw detector produced by KROPUS (Moscow, Russia). In some flaw detectors of universal type, such as EDDYCON C type flaw detector produced by PROMPRYLAD (Kyiv, Ukraine) or ELOTEST M2 flaw detector from Rohmann $\mathrm{GmbH}$ (Frankental, Germany) resonant mode is applicable as additional

\subsection{Selection of ferrite core parameters for single-coil EC probes}

The EC probe design selection is one of the most important and difficult stage in the creation of a probe of high quality. The sensitivity and other performance characteristics of the single-coil ferrite core EC probe depend on the diameter $D_{f}$ and the length $l_{f}$ of applied ferrite core, the length $l_{w}$ of coil related to the number of turns $w$ and wire diameter $d$ (for single-layer coil) and offset $l_{o}$ between the coil 
winding and the ferrite end as presented in Fig. 1a. All mentioned above parameter influence an EC probe performance in different ways, and these effects are a subject of many investigations.

Special EC efficiency coefficient $\xi$ was proposed earlier as an effective dimensionless parameter for an EC probe performance characterization [17]. The conditions needed for proposed coefficient investigation and the invariant properties of EC efficiency coefficient $\xi$ for air-core coils in relation to coil diameter and the number of turns were shown [18-19]. This methodology based on the volume integral code (VIC-3D code [20]) calculations was successfully applied to optimize the ferrite core EC probe design in contrast to other experimental or simulation methods [14-16, 20].

The influence of the ferrite core on the single-coil EC probe efficiency was investigated by simulation of the probe with different number of turns (from 1 to 100). For comparison, the same EC coils without core were simulated also. It was investigated the dependence of the EC efficiency coefficient $\xi$ on the number of turns when coil turns are wounded directly on the core with the length $10.0 \mathrm{~mm}$ and material initial permeability $\mu=100,600,1200$, and 2000 without offset $\left(l_{o}=0\right)$. The calculations were carried out for the operational frequency of $10.0 \mathrm{MHz}$. The dependencies of the EC efficiency coefficient $\xi$ on the number of turns $w$ for the coils without core $(\mathbf{a})$ and with ferrite core with different initial permeability $\mu$ are presented in Fig. $1 \mathrm{~b}$.
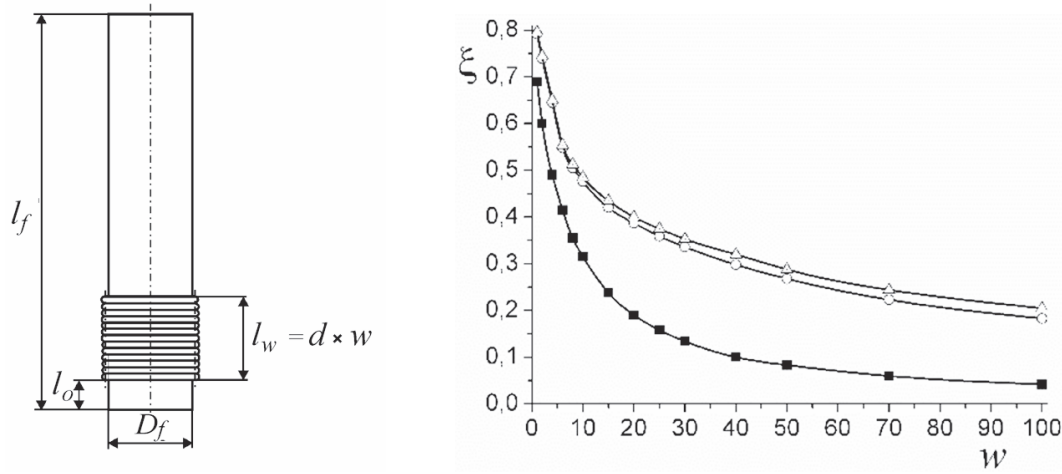

Fig. 1. Design of ferrite core single-coil EC probe (a) and dependences of the EC efficiency coefficient $\xi$ on the number of turns $w$ for the coils without core $(\mathbf{\square})$, and with ferrite core with initial permeability $\mu=100(\circ)$ and $\mu \geq 600(\Delta)$.

The dependencies obtained (Fig. 1b) show that the efficiency of a single-layer coil installed on the ferrite core increases by several times depending on the number of turns and consequently the length of the coil. With increasing the coil EC length, the efficiency coefficient $\xi$ is reduced. The dependencies of the coefficient $\xi$ obtained for permeability $\mu=100$ and $\mu=600$ are close enough. The dependencies of the coefficient $\xi$ on the number of turns (or coil length) for $\mu=600,1200$, and 2000 are practically identical and merged into a single curve. The last result can be confirmed by the dependence of the coefficient $\xi$ on the initial permeability $\mu$ (Fig. 2a). This dependence was calculated for a single-layer coil consisting of 25 turns wounded by $0.06 \mathrm{~mm}$ diameter wire placed with $0.5 \mathrm{~mm}$ offset on the ferrite core characterized by $1.2 \mathrm{~mm}$ in diameter and $7.0 \mathrm{~mm}$ in length. These results (Fig. 2a) show that with the initial permeability $\mu$ increase from 100 to 2000 , the coefficient $\xi$ increases from 0.24 to 0.27 . However, the greatest increase was observed on the initial section of dependence (up to $\mu=500$ ). With further $\mu$ increase, the efficiency coefficient $\xi$ growth is negligible.

Next dependencies (Fig. 2b) show the influence of EC efficiency on a ferrite core length and a location of $\mathrm{EC}$ winding. For this investigation, 25 turn single-layer winding mounted on the $1.2 \mathrm{~mm}$ diameter ferrite core was simulated. Calculations were carried out with ferrite nominal initial permeability 
$\mu=500$. The EC efficiency coefficients $\xi$ for EC probes with different ferrite lengths were calculated for winding placed directly on ferrite end without offset $\left(l_{o}=0\right)$ and for winding installed with a $0.5 \mathrm{~mm}$ offset $\left(l_{o}=0.5 \mathrm{~mm}\right)$. The efficiency of the air-core EC probe (without ferrite) also was calculated and was about 0.025 . Presented in fig. $2 b$ results show that the use of ferrite core increases the efficiency of the EC probe. For coils placed at the end of the core, the coefficients $\xi$ increase 7 times even for a core length of $0.5 \mathrm{~mm}$. The coefficients $\xi$ and, consequently, the effectiveness of the EC probe increases with the length of the core. When you reach a certain length (about $5 \mathrm{~mm}$ for a given winding), the efficiency increase slows down and when you reach $l_{f}=10.0 \mathrm{~mm}$ is close to the maximum value. The results show that the length $l_{f}$ of the ferrite core advisable to select in a range from 6.0 to $10.0 \mathrm{~mm}$. In this case, the efficiency of EC coils mounted with a $0.5 \mathrm{~mm}$ offset is decreased not so strongly as for short cores up to $l_{f}=2.0 \mathrm{~mm}$. For a core length $l_{f}=10 \mathrm{~mm}, 0.5 \mathrm{~mm}$ offset reduces the EC efficiency coefficients $\xi$ at 1.45 times. Such losses can be considered admissible. It should be noted that the use of ferrite core increases significantly and the absolute value of the EC probe inductance.
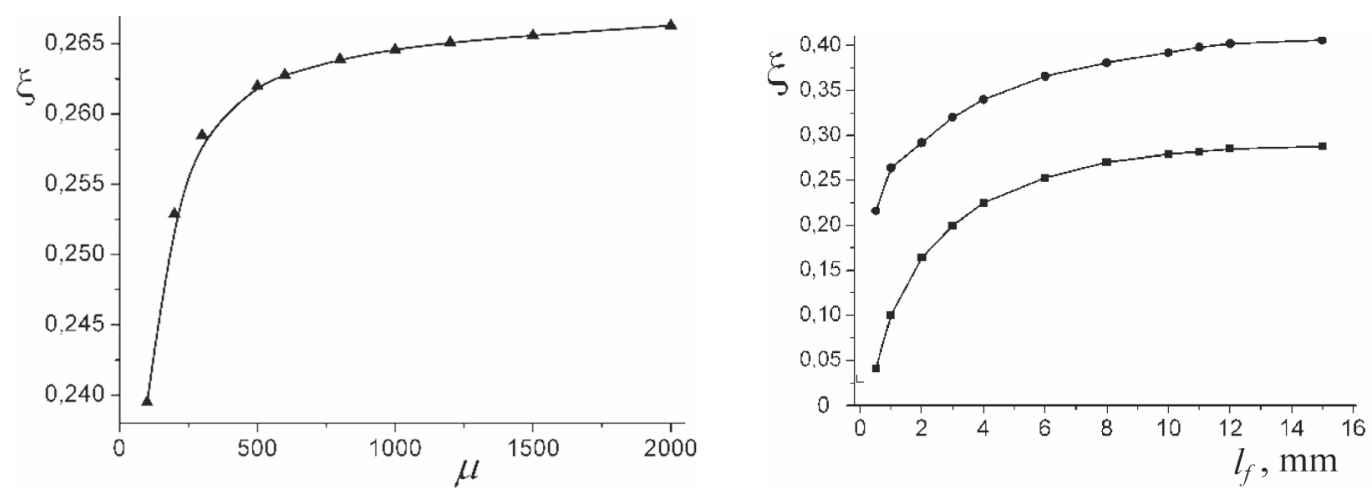

Fig. 2. Dependences of the EC efficiency coefficient $\xi$ on the initial permeability $\mu$ (a), and on the ferrite core length $l_{f}$ for windings placed at the end of the core $(\bullet)$, with offset $l_{o}=0.5 \mathrm{~mm}(\mathbf{-})(\mathrm{b})$.

Results presented in Fig. 1a and Fig. 2b concerned with low initial permeability influence can be explained by demagnetization factor which is particularly strong when coils are placed at the core end. Results obtained show the unreasonableness of the application of ferrite cores with high (more than 500) values of permeability for EC probe design. Similar way, the EC probes with different offset $l_{o}$ also were investigated. It was shown that offset $l_{o}$ (Fig. 2b) increase seriously influence the deterioration of the EC probe sensitivity characteristic. At the same time, some offset $l_{o}$ is needed to prevent possible EC probe destruction due to the wear during the probe scanning along the inspected surface. Results obtained are helpful for EC inspection operators to understand the changes in EC probe performance characteristics when some part of the ferrite core is worn out after a lot of scanning procedures. Therefore, some acceptable compromise in offset selection is required. As a consequence of the presented results analyzing, the design of the EC probe characterized by 25 turns single-layer winding mounted with a $0.5 \mathrm{~mm}$ offset $l_{o}$ on the $l_{f}=7 \mathrm{~mm}$ long ferrite core and ferrite initial permeability $\mu=500$ was selected as optimal for short as long as $2 \mathrm{~mm}$ crack detection.

\subsection{Influence of crack length on the EC probe performance characteristic}

The spatial distributions of the signal of a single-coil EC probe for cracks of different lengths were analyzed in our study [21] with the goal to optimize the probe diameter and scanning parameters. The changes of EC probe signal amplitude (the modulus of EC coil impedance) along the cracks were 
calculated by volume integral (VIC-3D) code. Changes in the modulus $Z_{C r}$ of the EC probe impedance, introduced by the crack, were normalized with respect to the modulus of the EC probe impedance in the case of its location on a defect-free conductive material next way $Z_{C r}^{\prime}=Z_{C r} / Z_{0}$. The coordinates $y$ of EC probe placements along the crack were normalized in relation to the probe diameter $D$ as $y^{\prime}=y / D$. Calculations were carried out for a value of the generalized parameter $\beta=D / 2 \sqrt{\omega \sigma \mu_{0}}=6.28$, which corresponds to aluminum alloy with a specific conductivity $\sigma=20.0 \mathrm{MSm} / \mathrm{m}$ on an operational frequency of 1.0 MHz. The EC signal amplitudes were calculated for cracks with the normalized opening $c^{\prime}=c / D$ $=0.1$ and normalized depth $b^{\prime}=b / D=1.0$.

The spatial distributions of the EC probe signal for cracks of different normalized lengths $l_{C r}{ }_{C r} l_{C r}$ $/ D$ (the ratio of crack length $l_{C r}$ to EC probe diameter $D$ ) from $l_{C r}^{\prime}=0.3$ (shortest crack) to $l_{C r}^{\prime}=5.0$ (longest crack) are presented in Fig. 3. As shown in this figure, the character of distribution of the EC probe signal in the scanning path along the crack depends qualitatively and quantitatively on the ratio $l_{C r}^{\prime} l_{C r} / D$. For short cracks $\left(l_{C r}^{\prime}<1.2\right)$, the distribution of the EC probe signal amplitude has a doublepeak symmetric shape with a minimum at $y=0$ related to the location of the EC probe over the central point of a crack). Signal can reach zero for very short cracks when $l_{C r}^{\prime}<0.3$ (Fig. 3a). Any NDI engineer has to be familiar with this established fact during the interpreting of the inspection result when high diameter EC probes are applied. From the physical point of view, this phenomenon can be explained by the distribution of the EC current density, which has maximum value directly under the EC probe turns and is decreased to zero in the EC coil center (sometimes called as "dead" area). So, we have a zero signal for the short crack located completely in the central area of the probe and practically does not influence to the redistribution of eddy currents. And, the signal amplitude is maximal for the located under the turns of EC coil and strong influence the eddy currents. That is why, for short cracks $\left(l_{C r}^{\prime}<1.2\right)$, the distance between the maxima is approximately equal to the coil diameter and is equal to 1.0 in relative coordinates $\left(y^{\prime}=y / D=1.0\right)$.
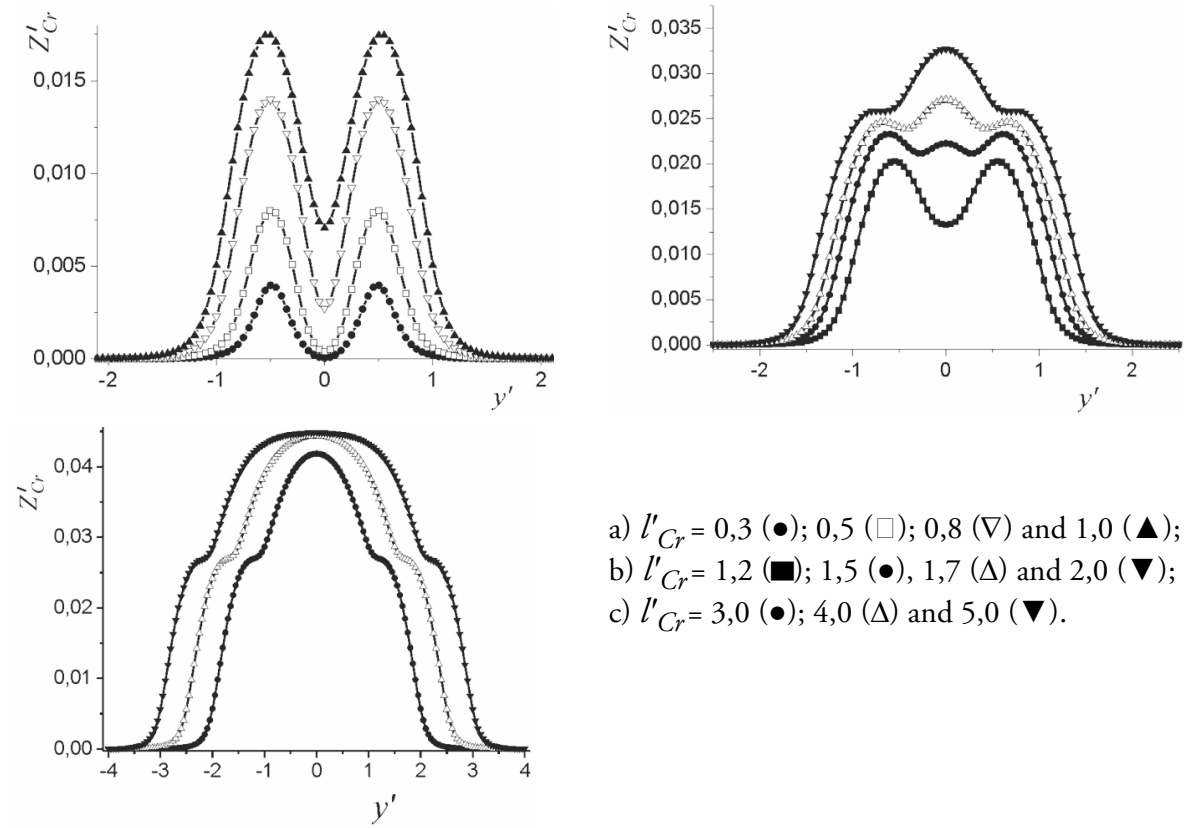
a) $l_{C r}^{\prime}=0,3(\bullet) ; 0,5(\square) ; 0,8(\nabla)$ and $1,0(\mathbf{\Lambda})$;
b) $l_{C r}^{\prime}=1,2(\boldsymbol{\square}) ; 1,5(\bullet), 1,7(\Delta)$ and $2,0(\boldsymbol{\nabla})$;
c) $l_{C r}^{\prime}=3,0(\bullet) ; 4,0(\Delta)$ and 5,0 $(\boldsymbol{\nabla})$.

Fig. 3. Spatial distributions of the EC probe signal amplitude for cracks of different normalized length $l_{C r}^{\prime}$. 
With the increase of the crack normalized length $l_{C r}^{\prime}$, the distance between the maximal amplitude values grows slightly (see Fig. $3 \mathrm{~b}$ for $l_{C r}^{\prime}=1.2$ and $l_{C r}^{\prime}=1.5$ ), and the signal amplitude at the point of minimum increases. When $l_{C r}^{\prime}=1.5$, the EC probe signal distribution has three maxima because with crack length increase the central minimum is gradually transformed into maximum. With the subsequent increase of the normalized crack length $l_{C r}^{\prime}$, the distribution of signal has a single maximum for the EC probe located over the crack center with two symmetric nearly horizontal parts on both sides. Growth of the crack length beginning from $l_{C r}^{\prime}=4.0$ (Fig. 3c) does not influence the signal amplitude for the EC probe situated in the central part of the crack. In addition, with the next $l_{C r}$ increase, the central maximum of signal distribution is broadened.

Analysis of the distribution of the signals of the EC probe (Figs. 3a and 3b) is evidence of a high probability of the omission of short cracks if the EC probe in the course of scanning gets to the central part of a crack. The presence of two maxima for short cracks can be interpreted as signals from two separate defects. Hence, the sizes of the EC probes are chosen smaller, proceeding from the technical requirements to the sizes of cracks that have to be detected. In the case where this is impossible, a decrease in the step of scanning enables one to detect reliably very short cracks. In general, the results obtained are agreed with the data of other researchers obtained for a smaller range of the crack length changes $[22,23]$.

Presented results were used for single-coil EC probe development. It was revealed, for example, that fatigue cracks of length more than $2 \mathrm{~mm}\left(l_{C r}^{\prime}>1.7\right)$ can be reliably detected by the EC probe supplied with the $1.1 \mathrm{~mm}$ diameter coil. As was mentioned above, this sensitivity threshold was established for the main aircraft applications. The obtained results are important for the selection of the optimal distance between the scanning lines. That is understandable that this distance also is dependent on the EC probe active diameter and a minimal length of the crack needed to be detected.

\subsection{Final decisions about single-coil EC probe design}

Presented above investigations were applied for EC probe design concerned with geometrical parameters selection. The existent nomenclature of commercial ferrite cores also was analyzed and taken into account. Two types of single-coil ferrite core EC probes were designed for the detection of the surface-breaking cracks in the aircraft industry. EC probe of a first type (identified as generic) was developed for detection as long as $2 \mathrm{~mm}$ cracks in aluminum, titanium, and other nonmagnetic alloys. This EC probe consists of one-layer 25 turns of 0.07 diameter wire mounted with 0.5 offset on the ferrite core characterized by $\mu=500$ initial permeability, $1.1 \mathrm{~mm}$ diameter, and $7 \mathrm{~mm}$ length. This EC probe is capable to solve about $99 \%$ of inspection problems concerned with surface-breaking crack detection in the aircraft industry. For the detection of cracks as long as $1.0 \mathrm{~mm}$, a similar EC probe was developed with a $0.7 \mathrm{~mm}$ diameter ferrite core application. For example, this probe was applied for the detection of a short cracks in aviation engine blades.

\section{DETECTION OF SURFACE-BREAKING CRACKS BY CONVENTIONAL FLAW DETECTORS}

\subsection{EC probe signals initiated by a crack and lift-off in the impedance plane}

The majority of modern EC flaw detectors are able to operate with single-coil EC probes in bridge or resonant modes [24]. Presented above EC probes were investigated by EDDYCON C type EC flaw detector in resonant mode. The operational frequency was selected as high as $1.0 \mathrm{MHz}$ to obtain high sensitivity to shallow cracks and the possibility to distinguish the useful signal associated with defects and noise created by the probe lift-off (the changes of the clearance between an operational surface of an EC probe and the surface of an inspected object). 
To suppress the lift-off influence, high enough operational frequencies are needed when the angle between the crack and lift-off influences is increased with operational frequency growth as it is sketched schematically in a complex plane diagram (Fig. 4a).

For our investigations, the special specimen fabricated from aluminum alloy with $30 \mathrm{~mm}$ long electricdischarge artificial like crack defects (marked as AF in Fig. 4b) with smooth A (Ra $1.25 \mu \mathrm{m}$ ) and rough B $(\operatorname{Rz} 160 \mu \mathrm{m})$ surfaces was applied (Fig. 4b). The surface roughness on the surface B was simulated by a sawcut grid. In specimen, the artificial electrical-discharge-machined $0.1 \mathrm{~mm}$ wide slots with depth $0.1 ; 0.2 ; 0.5 ; 1.0$ and $2.0 \mathrm{~mm}$ on the smooth surface $A$ and $0.6 ; 1.5$ and $3.0 \mathrm{~mm}$ on the rough surface B were fabricated. The defect-free area of this specimen was applied also to register the lift-off signal and scanning noise changes.
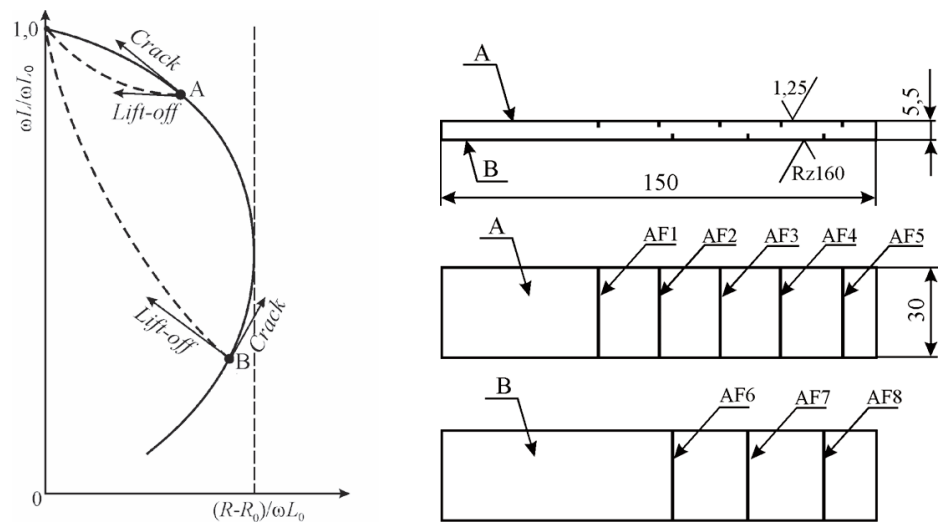

Fig. 4. Schematic complex plane diagram (a) of an EC probe impedance for different operational points and aluminum alloy specimen for EC probe investigation (b)

All slots in the specimen (Fig. 4b) were detected with a high signal-to-noise ratio. Deep enough defects in the rough zone were selectively detected in the mode of the low sensitivity due to a high level of the output signal. Even the shallowest $0.1 \mathrm{~mm}$ deep defect was detected with a high signal-to-noise ratio as presented in Fig. 5a. There is a dependence of EC probe signal amplitude on the defect depth. This fact can be applied for the sizing of the detected defects. As seen from signals in Fig. 5, the lift-off signal is oriented horizontally, and the signal created by the defect is directed upward. So, the angle between the useful and lift-off signals is about $70^{\circ}$. It is high enough angle to select the useful signal on the background noise created by hand scanning.
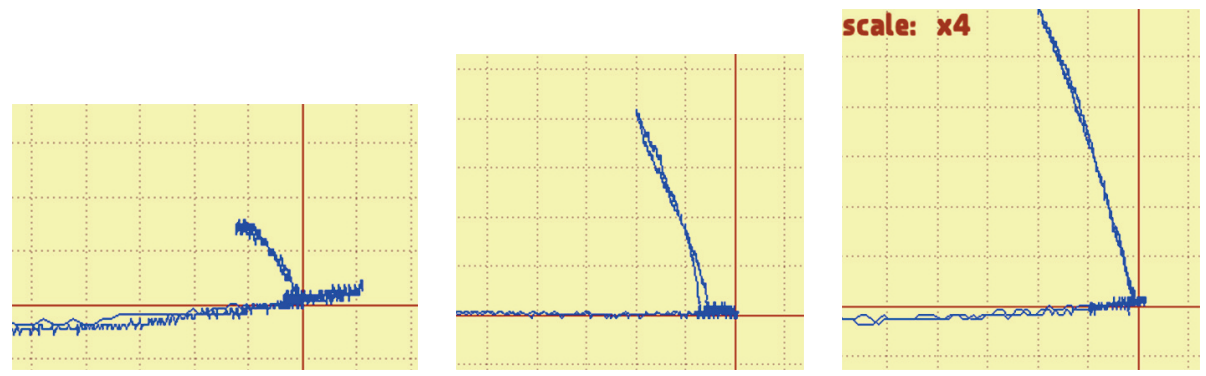

Fig. 5. Signals in the complex plane for $0.1 \mathrm{~mm}(\mathrm{a}), 0.5 \mathrm{~mm}(\mathrm{~b})$ and $1.0 \mathrm{~mm}$ (c) deep artificial cracks (upward) and signals produced by probe lift-off (horizontal). 
To investigate the sensitivity to short cracks original aluminum alloy specimen with $2.0 \mathrm{~mm}$ long and $0.1 \mathrm{~mm}$ wide electric-discharge artificial like crack defects was applied. The short defects of different lengths 0.2 and $0.5 \mathrm{~mm}$ were fabricated on the flat (defects 1 and 2), convex (defects 3 and 4), and concave (defects 5 and 6) surfaces as shown in Fig. 6a. Besides this, two 0.5 and $1.0 \mathrm{~mm}$ long defects (defects 7 and 8 in Fig 6a) were fabricated on the edge.
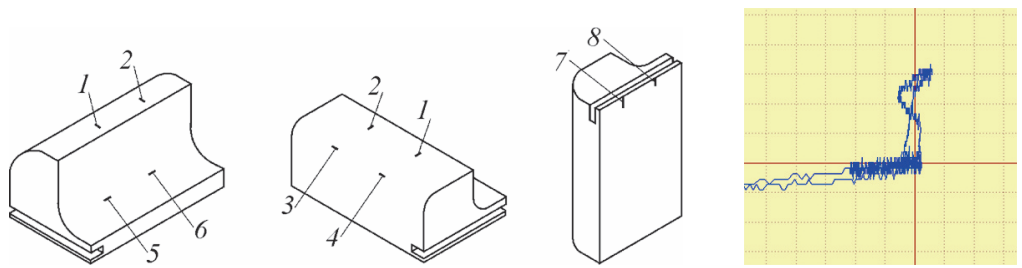

Fig. 6. Aluminum alloy specimen with short defects (a) and signals in the complex plane for $0.2 \mathrm{~mm}$ deep defect.

All slots in the specimen (Fig. 6a) were detected on the operational frequency of $1.0 \mathrm{MHz}$ with a high signal-to-noise ratio. The surface curvature of a $6 \mathrm{~mm}$ radius did not prevent us from defect detection due to the small operational surface diameter of the EC probe. As seen from signals in Fig. 6b, the liftoff signal is oriented horizontally, and the signal created by the defect is directed upward as presented before in Fig. 5.

Presented results (Fig. 5 and Fig. 6) show high enough sensitivity of the developed single-coil EC probe to shallow and short cracks and the possibility of reliable differentiation of the defect and lift-off by signal interpretation in the complex plane mode.

\subsection{Detection of the fatigue cracks in the vicinity of a rivet with the hole influence suppression}

Traditional EC detection of cracks situated near the rivet hole intends the circular scanning (Fig. 7b) in the rivet area with a constant distance from the edge due to high edge effect influence. In general, this procedure is difficult for operation during manual scanning and additional noise created by edge influence can restrict the inspection reliability. Selective EC inspection procedure for detection of the fatigue surface-breaking cracks originated from the rivet holes based on the developed single-coil EC probes application and the fine signal interpretation in the complex plane was proposed [25]. The proposed procedure supposes the possibility of differentiation of the defect signals and signals produced by rivet edge during handmade scanning in the rivet area under inspection. Scanning lines for preliminary evaluation of the influence of the rivet edge and detection of the cracks in the rivet area are presented in Fig. 7.
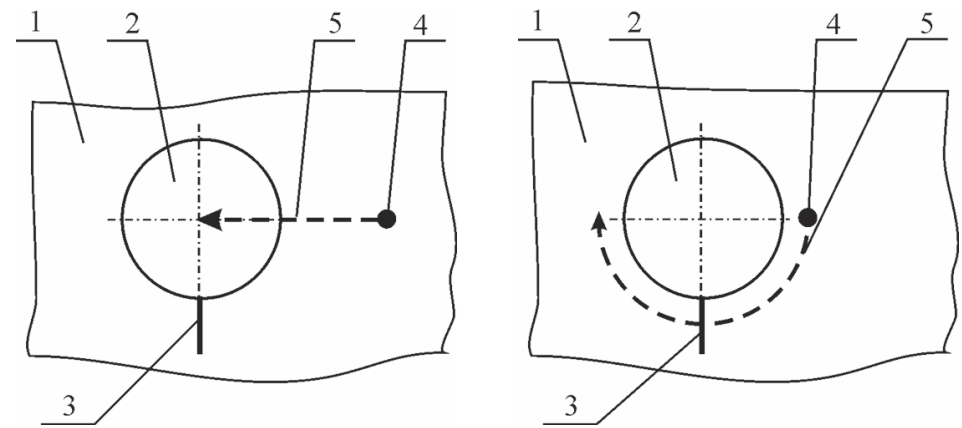

Fig. 7. Scanning lines for rivet edge (a) and crack influence (b) evaluation:

1 - skin, 2 - rivet, 3 - fatigue crack, 4-balance point, 5-EC probe scanning lines. 
The real fragment of the aircraft riveted unit with fatigue crack was applied for EC signals evaluation. EC signals in the complex plane were obtained for EC probe scanning across rivet edge (or the area of aircraft skin and rivet joint) (Fig. 7a) and for the circular scanning along rivet edge (Fig. 7b) were obtained and presented in Fig. 8. The lift-off signal in the balance point was evaluated also. Sufficiently great rivet edge signal was oriented horizontally (not lift-off as in Fig. 5 and Fig. 6b) by the complex plane rotation. In this case, the largest lift-off signal comes down to the third quadrant of the complex plane (Fig. 8). But we can distinguish the small signal related to the crack. For better defect signal and rivet edge distinguishing, additional amplification in a vertical direction can be applied as shown in Fig. 8b. After such adjustment, the scanning in the rivet area can be carried out in different directions not only with a constant distance from rivet edge. Presented rivet area inspection procedure was implemented into ANTONOV aircraft inspection practice.
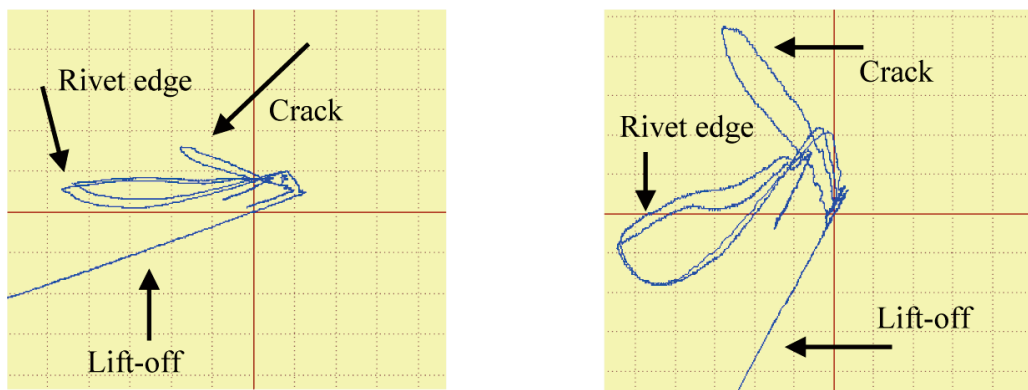

Fig. 8. Signals of single-coil EC probe in the complex plane for rivet influence oriented horizontally in the initial form (a) and after transformation (b): 1 - lift-off influence, 2 - rivet edge influence, 3 - fatigue crack influence.

\section{HIGH-FREQUENCY EDDY CURRENT FLAW DETECTOR BASED ON THE SELF-GENERATOR SCHEME}

Another approach for inspection with a single-coil type EC probe was realized by the using of the selfgenerator with a EC probe as part of an operational resonant circuit [10]. An important feature of the self-generating scheme is the way to suppress the lift-off influence (the changes of the clearance between an operational surface of an EC probe and the surface of an inspected object. It was shown that lift-off suppression can be implemented only in the overcritical mode (point B in Fig. 4a) obtained for large values of the generalized parameter $\beta=R \sqrt{\omega \sigma \mu_{0}}>5$ (where: $R-$ EC coil radius; $\omega$ - angular operational frequency; $\sigma$ - specific conductivity of inspected material, $\mu_{0}$ - vacuum permeability) [26]. As shown in Fig. 4a, in overcritical point B the signals associated with defect and lift-off have different sign of real components of the EC probe signal.

Self-generator type EC flaw detector (Leotest VD 3.03) was developed a few decades ago with the purpose to replace outdated flaw detectors developed earlier. In Leotest VD 3.03 flaw detector original scheme of double-circuit self-generator with intermittent oscillations was applied. Double-circuit oscillating system (Fig. 9a) is composed of active element VT1; the inductance L of the one-coil EC probe and the capacity $\mathrm{C}$ of the operational circuit; the inductance $L_{S}$ and the capacitance $C_{S}$ of the supporting circuit; the back-coupling capacitance $C_{F}$ and the biasing resistor $R_{B}$, and the capacitance $C_{B}$. The pulse-repetition frequency (frequency of passage of pulse packets of high-frequency oscillations) was used as the informative parameter for this type of self-generator (Fig. 9b) [26]. An important feature of the self-generating scheme is the possibility to suppress the lift-off influence. 

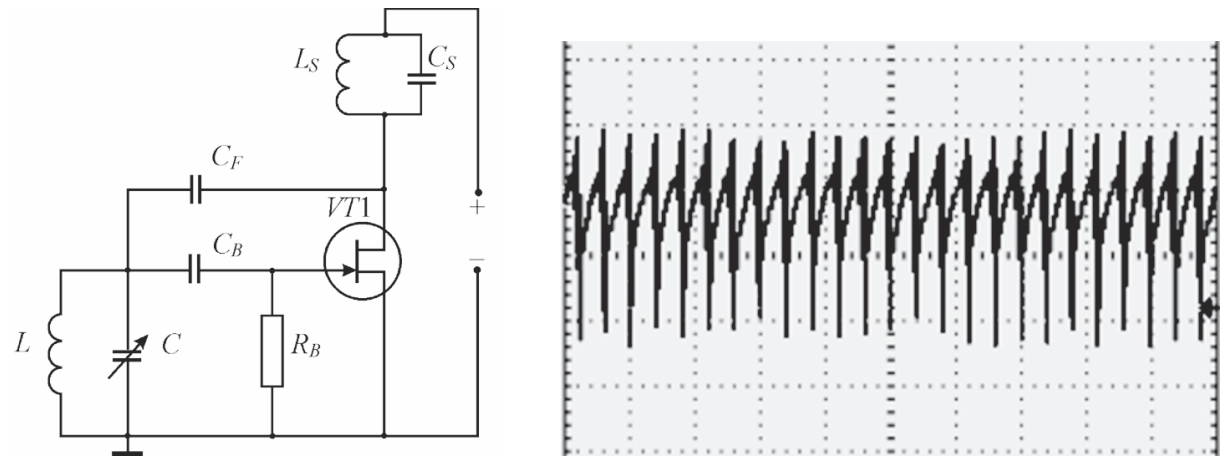

Fig. 9. Double-circuit oscillating system of self-generator type flaw detector (a) and pulse packets of high-frequency oscillations (b).

To ensure an elevated level of sensitivity, lift-off suppression, and inspection reliability three main inventions were proposed and realized [27-29], including:

1) Double-circuit self-generator based on the insulated-gate field-effect transistor, in which the feedback circuit is not loaded by the input impedance of the active element;

2) Efficient scheme for the operational circuit (resonant frequency) adjustment by voltage variable capacitor (varicap);

3) High-speed scheme for self-generator oscillation regeneration to ensure the advanced level of inspection productivity.

As a result of our investigations, the next performance characteristics of developed EC flaw detector were achieved:

1) High sensitivity to fatigue crack even when an inspection is carried out through a protective paintwork coating with complete lift-off suppression;

2) Possibility to reduce the influence of the edge of the inspected object (important for detection of cracks in the area of rivets and bolts);

3) Possibility to provide operation in difficult conditions (for example, on an airplane wing) with only the sound indicator as defect alarm;

4) Wear-resistant EC probes of different design (pencil-type, corner-shaped, for hole or thread area inspection, etc.);

5) Low power consumption and increased running time without recharging.

Due to the high-performance characteristics developed Leotest VD 3.03 flaw detectors are widely implemented into aircraft maintenance practice for in-service detection of surface-breaking fatigue cracks $[7,10,13]$. The devices are applied for inspection of the fuselage (Fig. 10a) and wing skins, the panels of the wing and center-section, wheel drums, brackets, blades, and discs of engines (Fig. 10b), etc. There was confirmed the ability to implement all typical EC inspection procedures for aircraft maintenance developed before for other EC flaw detectors. The techniques based on the Leotest VD 3.03 flaw detectors were implemented into the NDI inspection practice of ANTONOV aircraft and MOTOR-SICH aircraft engine components. 

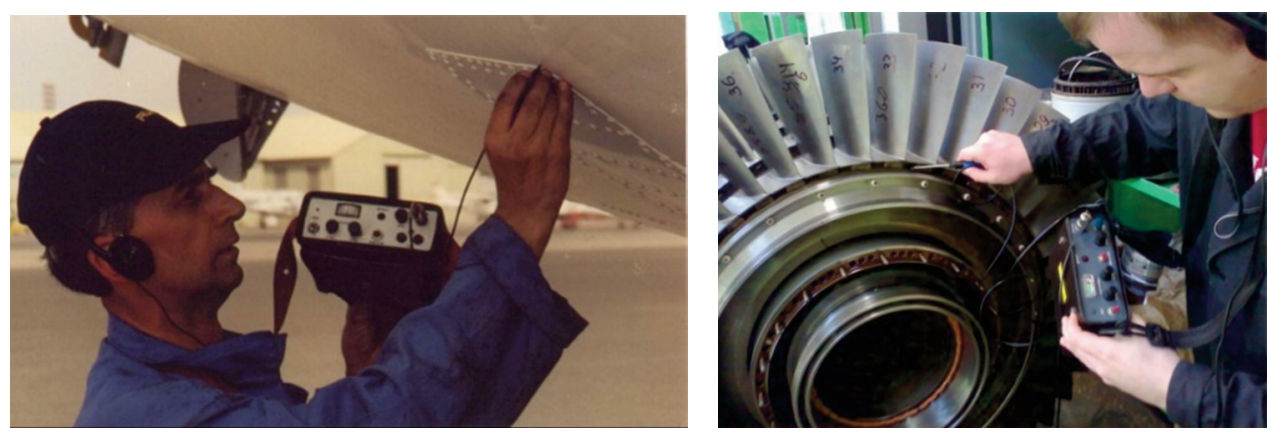

Fig. 10. Inspection of AN-12 aircraft fuselage (a) and engine components (b) by the VD3.03 type EC flaw detector.

\section{CONCLUSIONS}

Enhanced EC techniques developed for aircraft in-service inspection in the Karpenko PhysicoMechanical Institute of National Academy of Sciences (Lviv) are presented.

EC efficiency coefficient was applied for the selection of the ferrite-core EC probe parameters. Investigations concerned with the crack detectability for single-coil EC probes of different sizes were carried out to improve the inspection procedures. The qualitative and quantitative differences in EC signals for the ratio of crack length to probe diameter changed from 0.3 to 5.0 were established. Results obtained were used for optimal selection of EC probe diameter depending on the minimal crack length needed to be detected. For example, it was revealed that fatigue cracks as long as $2 \mathrm{~mm}$ can be reliably detected by the EC probe supplied with the $1.1 \mathrm{~mm}$ diameter coil.

The sensitivity of the developed single-coil EC probe was experimentally investigated. The possibility to distinguish the signals in complex plane associated with detected defect and lift-off influence was shown. The new inspection procedure was proposed for full suppression of the noise concerned with the rivet edge influence.

The high-frequency EC flaw detector of Leotest VD 3.03 type based on the self-generator scheme for detection of the surface-breaking fatigue cracks was presented. In this flaw detector, the original scheme of double-circuit self-generator with intermittent oscillations and pulse-repetition frequency of high-frequency oscillations as an informative parameter were used. The important feature of the developed self-generating scheme is the effective suppression of the lift-off.

Presented EC inspection techniques were implemented for the detection of the fatigue surfacebreaking cracks in aircraft structures and engine components.

\section{REFERENCES}

[1] Hagemaier, D.J., 1991, "Nondestructive testing developments in the aircraft industry", Materials Evaluation, 49(12), pp. 1470-1478.

[2] Schmidt, H-J., Schmidt-Brandecker, B., Tober. G., 2000, "Design of modern aircraft structure and the role of NDI", Insight, 42(3), pp. 141-147.

[3] Ball, D. L., 2003, “The Role of Nondestructive Testing in Aircraft Damage Tolerance”, Materials Evaluation, 61(7), pp. 814-818.

[4] Libby, H. L., 1971, Introduction to Electromagnetic Non-destructive Test Methods, New-York, etc: Wiley-Interscience.

[5] Udpa, S.S., More P.O., Eds, 2004, Nondestructive testing handbook (third edition), 5, Electromagnetic testing, American Society for NDT. 
[6] Uchanin, V., 2020, "Detection of the fatigue cracks initiated near the rivet holes by eddy current inspection techniques", Transactions on Aerospace Research, 1(258), pp. 47-58.

[7] Ostash, O., Fedirko, V., Uchanin, V. Bychkov, S., Moliar O., Semenets, O., Kravets V., Derecha V., 2007, Fracture mechanics and strength of materials, Vol. 5. Strength and durability of airplane materials and structural elements (in Ukrainian), Lviv, Spolom.

[8] Ostash, O., Uchanin, V., Semenets, O., Holovatyuk, Y., Kovalchuk, L., Derecha, V., 2018, "Evaluation of aluminium alloys degradation in aging aircraft", Research in Nondestructive Evaluation, 29(3), pp. 156-166.

[9] Hagemaier, D.J., 1991, "Application of crack detection to aircraft structures, Fatigue crack measurement: techniques and applications (Eds K.J. Marsh, R.A. Smith and R.O. Ritchie), Warley: EMAS, pp. 419-455.

[10] Uchanin, V., Derecha, V., 2006, "Eddy current method for detection of surface defects in aircraft units in in-service conditions" (in Russian), Technical Diagnostic and Nondestructive Testing (Kyiv), 4, pp. 20-28.

[11] Uchanin, V., 2010, "Surface type eddy current probes: extended classification, comparative analysis and typical examples of realization" (in Russian), Technical Diagnostic and Nondestructive Testing (Kyiv), 4, pp. 24-29.

[12] Uchanin, V., 2018, "Prepositions on improvement of the classification of eddy current transducers (in Ukrainian), Technical Diagnostic and Nondestructive Testing (Kyiv), 2, pp. 69-74.

[13] Uchanin, V., Aleksandrov, S., Tsiganov, V., 2009, "Eddy current flaw detection of aircraft engines in in-service and repair conditions" (in Russian), Bulletin of Engine-building, 2, pp. 151-155.

[14] Grubinskas, R.C., 1966, "An Evaluation of Probe Coils with Ferrite Cores for Use in Electromagnetic Testing", Materials evaluation, 10, 557-563.

[15] Capobianco, T.E., 1987, "Field mapping and performance characterization of commercial eddy current probes", Review of Progress in Quantitative Nondestructive Evaluation, 6A, New York: Plenum Press, pp. 687-694.

[16] Capobianco, T.E., Splett, J.D., Iyer, H.K., 1990, "Eddy Current Probe Sensitivity as a Function of Coil Construction Parameters". Research in Nondestructive Evaluation, 2, pp. 169-186.

[17] Uchanin, V., 2012, "Method of eddy current probe efficiency determination" (in Ukrainian), Ukrainian patent 42132.

[18] Uchanin, V., 2012, "Invariant efficiency parameter of eddy-current probes for nondestructive testing", Materials Science, 48(3), pp. 408-413.

[19] Uchanin, V., 2014, "Invariant parameter for eddy current coil efficiency estimation, 11th Europ. Conf. on NDT, Prague (www.ndt.net).

[20] Buvat, F., Pichenot, G., and Premel, D. 2005, "Eddy Current Modelling of Ferrite-cored Probes", Review of Progress in Quantitative Nondestructive Evaluation, 24, pp. 463-470.

[21] Uchanin, V., 2007, "Specific features of the space distribution of the signal of an eddy-current converter caused by cracks of different lengths", Materials Science, 43(4), pp. 591-595.

[22] Auld, B.A., McFetridge, G., Riaziat, M. and Jefferies, S., 1985, "Improved probe-flaw interaction modeling, inversion processing, and surface roughness clutter", Review of Progress in Quantitative Nondestructive Evaluation, 4A, pp. 623-634.

[23] Moulder, J.C., and Gerlitz, J.C., 1986, "Semi-elliptical surface flaw EC interaction and inversion: experiment", Review of Progress in Quantitative Nondestructive Evaluation, 5A, pp. 395-402.

[24] Uchanin, V., Lutsenko, G., Opanasenko, A., Dzhaganian, A. 2016, "PROMPRYLAD Family of Eddy Current Flaw Detectors - From Simple to more Complicated", 19th World Conf. on Nondestructive Testing, Munich (www.ndt.net).

[25] Uchanin, V., Derecha, V., Semenets, O., 2018, "Eddy current method for detection of the defects in the rivet area of aircraft structures" (in Ukrainian), Ukrainian patent 125679. 
[26] Uchanin, V., 2010, "Self-generator type eddy current flaw detectors: main principles, classification, comparative analysis" (in Russian), Technical Diagnostic and Nondestructive Testing (Kyiv), 2, pp. 18-23.

[27] Uchanin, V., Cherlenevskiy, V., 2008, ”Eddy current flaw detector" (in Ukrainian), Ukrainian patent 39207.

[28] Uchanin, V., Cherlenevskiy, V., 2009, "Eddy current self-generator type flaw detector" (in Ukrainian), Ukrainian patent 39217.

[29] Uchanin, V., Cherlenevskiy, V., 2009, "Instrumentation for eddy current testing” (in Ukrainian), Ukrainian patent 42132 .

\section{WZMOCNIONE TECHNIKI PRĄDÓW WIROWYCH DO WYKRYWANIA PĘKNIĘĆ POWIERZCHNIOWYCH W STRUKTURACH LOTNICZYCH}

\section{Abstrakt}

Odpowiednio wczesne wykrywanie defektów (np. pęknięć zmęczeniowych i uszkodzeń korozyjnych) w strukturach lotniczych jest zagadnieniem o kluczowym znaczeniu. Okresowa eksploatacyjna kontrola nieniszcząca (NDI) jest konieczna, aby zapobiec kosztownym awariom samolotu w trakcie jego eksploatacji. Metoda wiroprądowa (EC) NDI ma wiele zalet dla kontroli samolotów w trakcie eksploatacji ze względu na wysoką mobilność i możliwość wykrywania pęknięć zmęczeniowych bez bezpośredniego kontaktu z badaną powierzchnią (nawet przez powłokę ochronną bez jej usuwania). W ostatnich dziesięcioleciach w Instytucie Fizyko-Mechanicznym Narodowej Akademii Nauk im. Karpenki (Lwów), we współpracy z ukraińskimi i zagranicznymi firmami lotniczymi, opracowano udoskonalone techniki EC do kontroli eksploatacyjnej samolotów.

Zaproponowany wcześniej współczynnik efektywności EC został zastosowany do doboru parametrów ferrytowo-rdzeniowej sondy EC. Przeprowadzono badania dotyczące wykrywalności pęknięć dla jednocewkowych sond EC o różnych rozmiarach w celu poprawy procedur kontroli. Doświadczalnie zbadano czułość opracowanej sondy jednowstęgowej EC. Wykazano możliwość rozróżnienia sygnałów związanych z wykrytym defektem i lift-off*. Zaproponowano nową procedurę inspekcyjną umożliwiającą pełne wyeliminowanie szumów związanych z oddziaływaniem krawędzi nitów.

Opracowano wysokoczęstotliwościowy detektor wad EC typu Leotest VD 3.03 oparty na trybie samogeneratora i zastosowaniu miniaturowych jednocewkowych sond EC do wykrywania pęknięć zmęczeniowych pękających powierzchniowo. Wynaleziono i zbadano oryginalny schemat dwuobwodowego samogeneratora z przerywanymi oscylacjami. Jako parametr informacyjny wykorzystano częstotliwość powtarzania impulsów oscylacji o wysokiej częstotliwości. Istotną cechą opracowanego schematu samogenerującego jest skuteczne tłumienie wpływu zjawiska lift-off * (zmiany prześwitu pomiędzy sondą EC a powierzchnią badanego obiektu podczas skanowania).

Opracowane wykrywacze wad EC typu Leotest VD 3.03 oraz procedury kontrolne zostały z powodzeniem wdrożone do praktyki obsługowej w celu wykrywania pęknięć zmęczeniowych inicjowanych w strukturach skrzydeł i kadłuba oraz silnikach lotniczych w wielu firmach, takich jak ANTONOV AIRCRAFT, Lwowskie Państwowe Zakłady Remontu Samolotów, Konotopskie Zakłady Remontu Samolotów "AVIAKON", Ukraińskie Międzynarodowe Linie Lotnicze, MOTOR-SICH, Przedsiębiorstwo Państwowe "IVCHENKO-PROGRESS", itp.

Słowa kluczowe: prądy wirowe (EC), wykrywacz wad EC, jednocewkowa sonda EC, płaszczyzna złożona, struktura samolotu, pęknięcie zmęczeniowe, schemat samogenerujący, lift-off. 